\title{
Contemporary dance as being and becoming in the age of ageing - existential aspects of (arts) learning among older amateur dancers
}

\author{
Cecilia Ferm Almqvist \\ Södertörn University, Sweden (cecilia.ferm.almqvist@sh.se)
}

\begin{abstract}
Taking experiences from a contemporary multi-arts dance project as a starting point, this article explores how such a project can offer opportunities for being and becoming among older amateur dancers. The article takes a phenomenological approach, in which holistic experience and sharing of experiences are central. The phenomenon of the investigation is self-conceptualisation. The artistic process and context constitute an adult educational situation. To come close to the lived experiences of the dancers, the rehearsals and performance were observed and documented. Six of the participants were also interviewed. The material was analysed in a hermeneutical phenomenological manner, and Simone de Beauvoir's thinking regarding ageing was used as a theoretical lens. The results show how the self-images of the participants change during the course of the project. The dance activities seem to give the older participants opportunities to remain themselves, even as they allow themselves to change. They learn to know themselves, each other, and the world.
\end{abstract}

Keywords: Adult dance education, ageing, choreography, community dance, selfconception

\section{Introduction}

The right to express oneself and take part in cultural activities throughout one's life is expressed in different documents regarding human rights and law texts. For example, Article 27 of the Universal Declaration of Human Rights states that all human beings have the right to be engaged in cultural life and appreciate the arts (UNESCO, 2019). At a more local level the Swedish Fundamental Law on Freedom of Expression (The Swedish Parliament, 2015) and Swedish cultural policies (The Swedish Arts Council, 
2019) underline the right of all citizens - including older adults - to take part of and express themselves with artistic expressions.

With these fundamental rights in mind, this article follows a contemporary multiartistic dance project for older adults. Over the period of a year twenty older people sixteen women and four men aged between 65 and 85 years - participated in rehearsals for a dance performance that also included other artistic forms of expressions, such as music, art, photography and drama. The rehearsals were led by the choreographer Charlotta Öfverholm, and consisted of warming up, choreography and improvisation, as well as preparing. The process and performance were constructed from the participants' formulated life stories, which were shared in a performance, Stories, at the big dance venues in Stockholm. Most of the amateur dancers had participated in initial workshops a year earlier (Andersson \& Ferm Almqvist, 2021) and thereby knew the format and Charlotta Öfverholm's way of designing activities. ${ }^{l}$

I am a 54-year-old white female researcher with an academic background active within the area of music and dance education. For four years I have followed Charlotta's projects with the older amateur dancers as a part of a collaborative, arts-based research project. Apart from me and Charlotta, the research project also included a co-researcher, an assistant, and a professional photographer (Ferm Almqvist \& Andersson, 2019). The dancers had little or no experience of dance when they entered the workshop series. In the process of working towards the performance, the participants had the chance to use dance and individual artistic forms of expression in individual and collaborative choreographies and improvisational activities. The arts educational project explores, and analyses opportunities and challenges related to old age and equality. The ambition is to describe and explore how such a project can offer opportunities for being and becoming among older amateur dancers. I take phenomenological philosophy as a starting point, which implies that the lived experience of human beings constitutes access to phenomena. The following research question was formulated: How do older amateur dancers conceptualize themselves through artistic learning processes constituted by dance rehearsals and a performance?

\section{Adult learning in artistic activities}

As Wildemeersch (2019) states, arts or aesthetics in relation to lifelong learning can be viewed and explored in many different ways, based on various scientific grounds and philosophical ways of thinking. Dance and music learning processes among older adults are most often investigated within the research areas of community dance and community music (Camic et al., 2014), where wellbeing in relation to creativity constitutes a crucial concern (Hallam et al., 2013, 2014, 2016; Higgins, 2007). Liz Lehrman's (1976) initiatives and models for physical and creative modern dance activities with older persons constitute valuable pioneering work in this area. Social interactions including both participants and facilitators offer opportunities for everyone to express themselves, connect to life experiences, and find their identities in social relationships (Barr, 2013; Green, 2000; Hartogh, 2016). Such experiences are also found to contribute to social wellbeing among older adults (Camic et. al., 2014; In-Sil et al, 2015; Lee, et al., 2010; Pearce \& Lillyman, 2015; Phinney et al., 2014). That dance and music activities offer health and social benefits, and at the same time contribute to lifelong learning, is shown by the results of Söderman and Westvall's (2017) study of cultural activities in a Finnish society in Sweden. Another angle is explored by Laes (2015) who studied the process of learning music in bands involving older women. She states that the participants developed 
empowerment and musical agency. Further she discovered that the elderly could use their agency to understand the present and also provided tools for handling the future. Such an approach brings education among older individuals to the forefront and put well-being and health in the background of the situation. In this article, I am interested in how the older participants view themselves and their development in dance learning activities, over the course of one year, with the aim of being able to say something about adult education and how it can be organised for by society.

Arts learning can be understood to contain performative, tensional, structural related, bodily, emotional, and existential dimensions (Ferm Thorgersen, 2013; Nielsen 1998; Varkøy, 2017), all of which are relevant to adult education (Ferm Almqvist \& Andersson, 2019). Concepts like Bildung, or cultivation, are closely related to education and learning in the context of arts activities outside traditional school institutions. Bildung can be seen as a field of tension where experiences, relationships, and actions are formed, a field that includes existential - human related - as well as essential - content related dimensions. Hence, Bildung partly contains an inner, reflective, and self-constructive dimension, related to how a human being sees herself or himself and the world. Bildung also encompasses reflections upon what is learnt (Burman, 2018), in this case the essential dimensions of dance and music (Nielsen, 1998). Bildung as such is heavily laden with history, tradition, and ideals regarding human cultivation and educational goals. Still, it has the potential to frame and draw attention to various perspectives and understandings of the conditions for and the meaning of the formation of the human being (Burman, 2018; Varkøy, 2017). In this way, learning in and about the world, and oneself as well as developing a capacity for artistic expression are intertwined and happen simultaneously. From this perspective, Bildung can be characterised as an impetus for continually new learning and an openness to unknown and unexpected perspectives as well as a willingness to re-evaluate one's own values and imaginings (Ekberg \& Schwieler, 2020). Consequently, the view of Bildung used in this article includes existential dimensionsformation - and essential dimensions - cultivation.

In earlier studies of participation in dance workshops for older people (Ferm Almqvist \& Andersson 2019, Andersson \& Ferm Almqvist, 2021), it was stated that organised aesthetic communication offered participants opportunities to develop physically, emotionally, and existentially. These studies showed, in part, how the choreographer influenced opportunities for participation in terms of how workshops are designed and what inputs are given in the process, what atmosphere is created, how participants use their bodies, and how dance is offered as an artistic form of expression. Another interesting result of these studies was the demonstration, based on field notes and video recordings, that practising dance among older people accentuated four interrelated levels of activity conceptualised through Arendt's (1958) thinking about vita activa, namely: a functional body with an impetus to move; to embody dance as a form of expression; to use dance in aesthetic communication; and in reflecting on life, body and dance. Accordingly, the essential-existential intertwinement becomes obvious. In this article I am interested in increasing the understanding of how older adults conceptualise themselves in an artistic process where a dance performance was developed and performed. To be able to grasp such conceptualisations within adult education framed as artistic activities, I use de Beauvoir's (1976/1992) phenomenological investigation of age, and complete that with Merleau-Ponty's (1968) concepts of chiasm and flesh. 


\section{The coming of age and intersubjectivity}

All throughout her life, de Beauvoir engaged socially and politically with people considered as secondary, and therefore marginalised. When she discovered that she was met and treated differently than men, she decided to investigate what it means to be a woman, which resulted in her most famous work, the phenomenological investigation The Second Sex (1949). Through examining the phenomenon woman from all possible perspectives, she made clear that one is 'not born, but rather becomes, [a] woman' (de Beauvoir, 1949, p. 283). Hence, humans who are born female 'become woman' - the second sex - as a result of societal values and standards.

De Beauvoir's philosophical study of ageing, The Coming of Age (originally published in 1970), is also based on her own personal experiences: 'But the reason why I made up my mind to embark upon this book was that I needed to understand a state that was my own, and to understand it in its implication for mankind as a whole' (de Beauvoir, 1976/1992, p. 130). She wanted to break the silence around the topic of ageing. Older age, like womanhood, was perceived as 'the other', and widely marginalised and oppressed in society, according to de Beauvoir. A starting point was that an individual is conditioned by the society's theoretical and practical attitude towards her as an older person: 'An analytical description of the various aspects is therefore not enough: each reacts upon all the others and is at the same time affected by them, and it is in the undefined flow of this circular process that old age must be understood' (1992, p. 9). She begins by stating that the phenomenon of age cannot be studied from physiological and psychological perspectives separately, since biological change is situated and influenced by existential, historical, and societal circumstances and responses. Therefore, de Beauvoir studied how age showed itself 'from without' through scientific, biological, anthropological, and historical perspectives, as well as 'being in the world' through lived experiences of the same.

Her extensive phenomenological investigation concludes that it is old age - the unavoidable process of decline - exists in contrast to earlier life, rather than death: 'Old age is life's parody, whereas death transforms life into a destiny: in a way it preserves it by giving it the absolute dimension' (de Beauvoir, 1976/1992, p. 539). Her inquiry confirmed age as 'otherness' and 'oppression', and additionally showed how strong powers and norms to a great extent take away older human beings' empowerment, or agency, to run projects and make meaning in their lives. Hence, the study can be defined as a fierce indictment of society's indifference and cruelty toward old people. The degradation, the hatred of the elderly has to be taken into account, she underlines. The only way to lend old age dignity according to de Beauvoir is to give value to the life of others, by means of love, friendship, indignation, and compassion.

She also emphasises that class influences how ageing is experienced. Physical and mental damages cannot be repaired in advancing age. The huge space between those privileged, either by talent or class, is extended in the case of the old. The study illuminates that millions of people are abandoned, as if while still breathing they were already dead, buried alive. Hence, she asserts that human beings must be treated in human ways all through life, and that in turn puts demands on the way a society operates.

De Beauvoir (1976/1992) suggests there is only one solution to aging becoming a parody of life, and that is to participate in activities that give life meaning. She points out that the ageing body is transformed not only in the physical sense, but more importantly in the sense of restricted existential possibilities, and she stresses the need to 'go on pursuing ends that give our existence a meaning - devotion to individuals, to groups, or to causes, social, political, intellectual, or creative work' (de Beauvoir, 1976/1992, p. 
540). She further stresses that older people must accept new images of themselves in order to resolve identification crises and live a meaningful life. It should be underlined though, that an existential phenomenological way of thinking does not account for psychological or medical views of human bodies and developments but should be seen as one of several perspectives.

The transformation included in changing images of oneself can be understood with the help of Merleau-Ponty's (1968) metaphorical concept of chiasm, which also inspired de Beauvoir's thinking about situatedness. Merleau-Ponty (1964) underlines that human beings are not self-contained subjects, but beings who are formed in and through social interactions. Expressed by the Greek letter $\chi(\mathrm{chi})$, chiasm means a crisscrossing of the perceiving and the perceived, of self and other, and of language and meaning - based on human beings' bodily being in the world. Additionally, the concept accentuates intertwining or intersection and reversibility - in other words, processes where phenomena flow into one another. Merleau-Ponty (1968) uses the metaphor of 'flesh' to represent an image of 'Being', which includes chiasmic spaces and gaps between human beings and the world, wherein they are intertwined and ensnared in relationships. Flesh as Being gives rise to the perceiver and the perceived as interdependent aspects of subjectivity.

Chiasm can be viewed as a situated confrontation involving individuals and groups, who can change and transform their life-worlds through common action (Merleau-Ponty, 1968). The transformation of self-conception can be viewed as a process where the flow of action is intertwined with the flow of thought, a process where new experiences are reflected and offers new views of oneself, others and the world. It is within the chiasm that older dancers' perception is doubled, embodied, and entangled. Consequently, Merleau-Ponty's (1968) thesis of reversibility proposes that 'to see' opens up the body to others. It is one way of knowing and being formed in closeness and through encounters that constitutes the base for transformed self-conceptions, and by that lifelong learning.

\section{Methodology and methods}

To come close to the lived experiences (Merleau-Ponty, 1962; Bengtsson, 1998) of the older amateur dancers both the rehearsals and performance were observed and documented by field notes and video recordings in May 2017, November 2017 and May 2018. Field notes were taken throughout the workshop series, and the activities were video recorded with a stable and a mobile camera operated by a professional photographer. I recorded some of the sessions myself, using my tablet. The twenty participants, four men and sixteen women, 65-85 years old, were encouraged to bring written stories based on their life experiences, and these were used and interpreted in the workshops. The participants were also asked to include other familiar forms of expressions in the performance, as drama skills, instruments, photographs, painting equipment, or specific dance artefacts. The material that forms the main source for analysis in this article though, consists of transcribed interviews with six of the participants, four women and two men, aged 70 and 72, and four women 86, 80, 80, and 79 years old. The six interviewees live in, or close to the capital of Sweden and represent the middle class in Sweden. Two of them were born outside of Sweden, in Great Britain and the USA.

The areas covered in the interview guide were reasons to participate, experiences of participating, being and becoming in the dance activities, and physical and emotional reactions connected to age. The interviews lasted for 50-60 minutes each and were 
transcribed verbatim, resulting in 40 pages of text. Approached phenomenologically, the text is seen as a broad collection of expressed lived experiences, that collectively give access to the phenomenon. For this reason, individuals are not referred to in connection to specific quotations.

The transcriptions were analysed using a phenomenological hermeneutic perspective (Alrø \& Rønholt, 2003; van Manen, 1990). The process of analysis included naïve reading, structured analysis, comprehensive understanding, and the formulation of results in a holistic manner. In other words, the interviews were first read several times in order to grasp their meaning as a whole. This naïve reading was followed by a phase of structural analysis - a way of identifying and formulating themes that provided opportunities for testing the emerged concepts. A theme is a thread of meaning that penetrates parts of a text in the process of conveying the essential meaning of lived experience. The process was finished when the themes validated and deepened the naïve reading. Then, the main themes and constituting aspects were summarized and reflected upon in relation to the research question and the context of the study, and finally, the last step concerned formulating the result in a situated language. The last step also included finding quotations from both the participants and de Beauvoir that showed the different sides of the phenomenon in concrete ways and illuminate how an artistic dance project can help to challenge existing structures and policies related to adult education, as well as offering suggestions for what life-long learning could be.

\section{Dance as transformative being and becoming}

To view oneself as a human being with a meaningful life, and not an old person, seems to demand change in many senses. The analysis of the material made clear that this change concerns the following transformations: from being seen as a 'what' to a 'who', from oppressed to equal, from being what you already are to becoming your full potential, from materialised conceptions to bodily experience, from the known to the unknown, from long past habits to future directed projects, and from the individual to intersubjective relations. In what follows, each theme is presented through descriptive text and quotations from the six interviewed older dancers which specifies the terms. Based on a phenomenological way of thinking, the material is seen as a whole, and the quotations are not related to information about the individuals. Each section is introduced by a quotation from Simone de Beauvoir's The Coming of Age (1976/1992).

\section{From 'what' to 'who'}

From the outside the old man is the object of a certain knowledge (de Beauvoir, 1976/1992, p. 10).

The change from 'what' to 'who' among the participants concerns the transformation from being viewed as an old person, to being seen as a human being participating in a multi-artistic creative process - as a person who has something to say artistically and is able dance together with others. The project demonstrates that such a transformation is based on curiosity and mutual respect. The interviewees express that in the beginning they talked about their ailments and injuries, but soon they abandoned those subjects and began to talk about makeup, the dance, anxiety, the group, and the challenges and opportunities in the performance. They talk about what they do together. They talk about 
how they see each other and themselves; and they compare this to how they are met in ordinary life - as 'whats'.

The participants testify that they experience this transformation based on warmth, on seeing each other as individuals, as persons. They see each other as humans with different sides, and the cracks caused by age are moved to the background.

Yes, I experience warmth to a greater extent, and everyone has become a person, everyone has become individuals, and I mean, even [though] I am a senior and you can see all cracks, now you see a person.

In addition to their experience of warmth, reasons cited by interviewees for the transformation include the new and creative way of thinking about working with older people, in which older human beings' bodies and movement are given space and are taken seriously and worked collectively within the form of contemporary dance. That they all fall within the age bracket of 65 to 85 is also seen as a prerequisite for the way in which they are able be open to each other. The focus lies on expressing oneself in dance, individually and together, and working towards the performance.

Moreover, part of the transformation is the development of a common message to the audience and society which emerges during the process. How they are approached and supported by the choreographer is also mentioned as an important prerequisite for the transformation from being seen as a 'what' towards being seen as a who; this will be further developed below. They trust the choreographer fully, and they really appreciate being full members of the developing artistic process and performance.

\section{From oppressed (the other) to equal}

We will discover, through the words and actions of others that we now belong to the social category of those who, no longer having a useful function, modern society designates as 'pure objects' - as not worthy respect (de Beauvoir, 1976/1992, p. 88).

A wider view of the transformation or change is to see it as a move from experiencing oppression to experiencing equality. An important catalyst for this is being approached and met seriously. But the first step that the interviewees mention is the very fact that this kind of activity is actually offered to older people.

They feel invited and involved, as artists and as participants in the creative process and the coming performance, through the sharing and treatment of their stories, upon which the whole performance is built. They appreciate having had the opportunity to decide what they wanted to share and in what ways, and that their messages are taken seriously.

At the heart of the participants experience of being taken seriously by the choreographer is the fact that she sees them and believes in them as dancers and artists capable of developing and performing at the large dance venue in Stockholm. The choreographer is appreciated because she offers direction and knows what she wants. Not least, the participants perceive that she wants authenticity, which demands presence. She opens spaces in such a way that the participants feel that there is space to be creative, but that they cannot do just anything.

You listen, and then you do.

The participants also recount that Charlotta changes her mind very quickly, and they feel they must be prepared for that. These changes of mind concern corrections, transfers, and 
re-buildings. The closer they get to the premiere, the stricter she gets, and the participants seem to like to receive critique, and to be corrected. That is experienced as a part of be taken seriously.

Well, I think all of us appreciate Charlotta very much, which makes us able to enjoy her, independent of what she does. And when she says 'no', or when she gets angry, or when she thinks that we should do things in totally other ways. Or when she says that we look like a 'kindergarten' which she said one day. You never take what she says as criticism. And that is very special. I have never met that before.

They also trust that the piece will come together as a whole even though at the time of the interviews time was short, and all the bits and pieces were creating chaos and feeling like a mess. One of the participants does raise a concern, however, that a hindrance to her own transformation towards equality is that she doesn't hear well due to an accident a year ago; she would have liked the choreographer to wear a microphone. She says that it is possible to ask each other what was said, but then it is easy to miss the next message.

\section{From being an old human to becoming her full potential}

We must live a life so committed, so justified, that we can continue to cherish it even when all our illusions are lost and our ardour for life has cooled (de Beauvoir, 1976/1992, p. 567).

One aspect of change connected to self-image is to see oneself as not finished, to see that new things can be learnt, and that one can handle oneself in new ways in new settings. It is about becoming one's full potential. One way of doing this is to go into new roles, to use the whole body in new ways, and to make new discoveries, or just to participate in a performance at stage, which the project also both encourages and demands.

She takes us seriously and she uses all participants potential at a maximal level.

A precondition for becoming one's full potential is to be open to the idea that new learning is possible - to see yourself as a learner, to see the situation as a place to try new things, and also to bracket earlier experiences, to be open to what the new situation can offer. The participants express that they have been encouraged to use their bodies in new ways, which in turn inspire new movements that they hadn't been aware they were capable of. They also say that such experiences give something back to their whole selves.

It gives energy to how the body functions.

Adopting new roles happens at both the abstract and concrete levels. One of the participants recounts a situation in which they all tried on clothes for the performance. Suddenly he saw young people, and he describes how strange this transformation was and how he was mirrored in the appearance of the others. A part of that process for him was the experience of being able to move, to actually dance, in ways they hadn't imagined earlier:

I can dance, and it doesn't become very strange.

It has become clear to the participants that they do not think of anything else when they are participating in the artistic process. They are aware that concentration and focus are needed. They express that they have learnt to be in the moment, to be present, which also 
is a part of being your full potential, and that this is the core when the premiere is coming closer.

Yes, but I think that has become more and more easy, or more important, or how to express

it, to keep the presence, the closer the seriousness is coming. With the premiere.

The sense of how important it is to do one's best encourages the participants to be as present as they can.

An important aspect, though, seems to be that the choreographer sees the potential in the human bodies and encourages them to stretch out from where they are. She makes it possible for the participants to create something based on their life experiences and preconditions. She sees potential in their movements, hears when they feel uncomfortable, and identifies alternative ways to develop what is already there. They appreciate that she sees nuances in movements, that they are not expected to look like ballerinas, they are not expected to be perfect, it is even accepted to express oneself in ugly ways.

\section{From being in the known to being in the unknown}

To go on pursuing ends that give our existence a meaning - devotion to individuals, to groups, or to causes, social, political, intellectual, or creative work (de Beauvoir, 1976/1992, p. 540).

It became obvious through the analysis that being in the unknown is an important step toward changing the image of self and finding meaning. It is about daring to lose control, being in a state of exploration and discovery, and being in the art, which the project also both demands and makes possible - it is being in the space of wonder.

Several of the interviewees describe the excitement of being in the dance. They say that it is hard to put in words what happens when they use their bodies in dance as a form of expression. Either they take an instruction, for example to improvise with a specific set or kinds of movements, or they are encouraged to experiment with a specific feeling.

The analysis also makes clear that the space of wonder can be created in the interplay between different forms of expression: between spoken story and movement, or between music and movement, or vice versa.

Yes, it is just to internalise that content and letting it get an adequate expression. I don't know how to say it, that is something just possible to do.

Translation to another form of expression can also create spaces for wonder and discovery. For example, one participant tells of when she was encouraged to tell her story in English (which is her mother tongue) instead of Swedish. She says that it was a relief to tell it in Swedish, because that gave her distance from the painful history of her life. When she told it in English, she came very close to the experience and it hurt in another way. So, she started to cry, which she did not do at all when she told it in Swedish. She found it interesting to be out of control of her feelings. The same feeling of giving up control is told by a participant who saw her story performed by others, even though she had initially rather wanted to dance it herself.

One word that is used for the creative activities is 'play'. Play opens a space for discovery, a possibility for which the choreographer sets the base, a platform. She encourages them and makes them safe, and she is balanced in her way for correcting. 'She is our play leader. 
It is defined by the participants as an adventure, a discovery, and a deep experience, where they have the opportunity to get to know their bodies in soft, smooth movements.

The participants say that being part of a creative process close to the premiere of the show is an experience of the unknown. They did not know how it will be in the end, or whether they will be able to participate in a way that would make it a worthwhile experience for an external audience. At the time of the interviews, they had a feeling of chaos: 'We forget [what we have agreed upon] from day to day.' But they try to trust the structure the choreographer has in mind. Still many changes are made in the moment, as the choreographer gets inspired by something the participants do when they rehearse. They are prepared for changes to continue until the bitter end. And that is also expressed as a state of being in the unknown.

\section{From materialized conceptions to bodily experience - of age}

Can I have become a different being while I still remain myself? (de Beauvoir, 1976/1992, p. 283)

Another aspect of self-image is the assumptions regarding what it means to be an old person, and how such a person is expected to behave. In the project conservation of traditional age patterns and structures become open to challenge. One way of challenging materialized conceptions showed to be to offer bodily experiences of what a person is and what she can do, through dance or other artistic expression.

The participants talk about movement as a prerequisite for life, for creating and creativity. Throughout the project the participants have discovered that they want to be creative human beings for as long as they can. There are lots of comments in the material regarding how alive they feel when they are in the dance. Not least, they appreciate the interplay with music.

I just feel so alive. When I am in the dance, I feel that I live and is in deep contact with myself. I just to go into the feeling that the music awakens inside of me.

Dance and movement are perceived as ways of keeping young - of evidence that the body can remain lively and mobile. The participants say the dance helps them to age in meaningful ways. They see the risks of saying, 'I am too old, I can't do this'. And they understand that such an attitude can lead to them sit down and get stiff. Instead, they appreciate the access to dance and movement as a life affirming opportunity. The participants also accentuated the opportunity to force the body to remember patterns of movement as a means for them to stay lively and attentive.

To some extent the analysis shows that older human beings have not been expected to move their bodies in lively ways, and that shyness and body awareness have hindered them from moving freely. Expectations about what kind of dance older can participate in have also been shown to create barriers to the full use of the body.

Yes, it is joyful, because now I get to use the upper body as well. Because in the kind of dances I have practiced earlier, it is only the lower part that is moved. You just follow, and the legs are moving.

But on the other hand, the participants state that, because they are older, they do not have so much to lose, and they dare to try and to investigate. When the barriers are taken down, and the 'eye from the outside' is not taken into account, the older have much to give, and 
they play together in the dance. When the old body seems to be forgotten to a great extent, pain is no longer felt, or it is handled in new ways.

\section{From limitations to future directed projects - from immanence to transcendence}

The greatest good fortune, even greater than health, is to have his world inhabited by projects: then, busy and useful, he escapes from both boredom and from decay. The times in which he lives remains his own (de Beauvoir, 1976/1992, p. 492).

Like other oppressed groups in society, older citizens have been silenced more or less consciously in society. Opportunities for older people have encouraged immanence rather than transcendence. The project reveals opportunities for older people to formulate and express inner thoughts and ideas, which provides directions for possible future directed projects.

The analysis makes clear that, for a human being who has not been listened to, finding one's own ideas and opinions - finding your own core - is a great achievement. To become true and authentic, according to the interviewees, all surface layers must be taken away in order to reach the core and start to grow from there.

Yes, for me dance is a sense of wholeness, you feel something, and then it is expressed with the body, there is nothing you hide. If you want you can hide it, if you want you can imitate, but you can also make it like a bridge between what I have inside and how I express myself outside. So, I think that is rather exciting.

The sharing of stories seems to be crucial to breaking limitations and having the opportunity to run their own projects allows the dancers to transcend their bodies. Most of the participants greatly appreciate the opportunity to share what they have been holding inside for a long time. The opportunity - even demand - to use their bodies to express experiences and feelings in artistic ways make them happy.

And I want something with that. And that is really important, but it becomes very focused and strong inside me. And of course, I feel happy.

The choreographer tells the dancers that they are on a journey of discovery with their own expression and their own bodies. She encourages them to take advantage of that and encourages them to be 'more' and 'wilder'; she urges them not to be careful and anxious, but to dare be rough and ugly. By that, the participants discover that they can use more of their inner powers.

The playful approach promotes creativity. The material shows that the dance gives the participants possibility to explore a variety of feelings. They talk about how they translate a feeling into a movement. The improvisational duets are especially mentioned in connection with this aspect.

The interplay with music is also underlined as important in activities of expressing oneself and running one's projects, to use de Beauvoir's concept. They talk about how the music nurtures movement inside them.

Yes, it is so wonderful to let oneself be filled with music and that a movement becomes expression of that feeling you are filled with.

Both the creative playful work and the choreographer inspire the participants to use other forms of expression in the same manner. One of the participants is asked to paint, live, on 
stage, as a part of the performance. Others play instruments, share photographs, and dance styles they knew since before.

Hence, the participants have been trained and encouraged to express themselves with their bodies individually and collectively, to listen to each other, and to be clear to each other. They also emphasize that they will have the opportunity to express themselves onstage - giving an extra dimension to their ability to express their thoughts and ideas artistically.

It becomes some kind of focus in the body, which makes it really exciting. It gets tense, it gets happy, but I do not stand there for my own therapy's sake, I have to think about the audience. I must think about the beholder.

The task for the choreographer, among other things, is to put all the individual-based scenes together in a way that intertwines the individual projects, in time and space. She works with the group to create one whole piece out of the different parts, with transitions in between.

\section{From the individual to intersubjective relations}

Life without culture, interests and responsibility denies transcendence, it denies ambiguity. In order to embrace ambiguity, each and every human being should not look forward to the coming age alone and empty handed. Ambiguity demands that society look upon women and men as useful at every age, not as atoms able to be negated by other atoms, but as part of a collective in which even the old can fulfil and renew their lives as they prepare to distance themselves last timer from the weight of the past (de Beauvoir, 1976/1992, p. 542$43)$.

Ageing has been viewed as something individual, even if that has started to change lately. In viewing ageing as a matter of intersubjective relations, this study brings to the fore the importance of sharing and responsiveness, while remaining honest with oneself and in interaction with others. Other important factors in an intersubjective-relations-based understanding of ageing are atmosphere, togetherness, and caring about one another.

Fairly early in the process the participants were asked to communicate bodily with each other, in pairs and groups. The participants recount that they learned to relate to each other in authentic, trustworthy manner. They were encouraged to learn from each other's ways of moving. They were trained to be responsive, and this was something they developed all through the process. Sometimes they had to do things they did not like, for example hugging each other in groups, in authentic ways, which was challenging in the beginning.

Based on the kind of communication the design of the workshops offered, a strong sense of togetherness was developed. To be together with others and to do things collectively is appreciated and experienced as meaningful.

We are not at this planet to live individual lives. We must decide to gather, because it doesn't look that great. To have these moments all the weeks we have worked together and feel this setting, and feel it without words, that's like heaven.

Some of the participants express that they do not want the project to stop. They do not want to return to loneliness. Doing things and investigating life together has energized them. 
And that the interplay with all the others in the group. It is so exciting, and one fantastic thing was, that after one day, we had lost ... or become safe with each other, all anxiety and tension disappeared.

The group scenes, the 'snake-pits,' are mentioned here specifically, where responsiveness towards others and one's own movements, authenticity, and the feeling of being a part of something larger are at the core.

When it works, then it is a great feeling of happiness, as you are a cog in this fantastic artistic machinery. And just create in a way, it is wonderful.

Because of the nonverbal communication and togetherness, the participants share that they have developed a great caring atmosphere together. 'It is clean, everything is clean, but emotional. It is a perfect combination.'

\section{Implications for adult arts education}

As mentioned, this study was driven by an interest to better understand how older adults conceptualise themselves in artistic processes, such as development and performance of collaborative contemporary dance. Through taking de Beauvoir's stated view of old age; The unavoidable process of decline, that exists in contrast to earlier life rather than death, I found that arts education can contribute to transformation of self-images among oppressed people, such as older citizens (cf Butterwick \& Roy, 2018). The results implicate that a starting point for successful educational or pedagogic arts activities have to account for transformation from being seen as a 'what' to a 'who', hence that the learners are seen as dancing human beings rather than old people. In addition, transformation concerns change from being oppressed to being equal, in other words to exist equally and have the possibility to be heard and seen, which the dance activities offers. Also, it seems important to encourage change from being what a human being already is, to becoming her full potential, independent of age, which makes dreams and imaginations important. Instead of letting materialized conceptions of age and long-past habits be conserved, it seems that well conducted dance activities instead can accentuate bodily experience of age and future directed projects. Finally, the importance of offering older human beings to develop inter-subjective relations is underlined, and it is clearly shown how arts activities can offer such situations. Conducting transformative activities for older people, that challenge established structures regarding age and ageing, demands that existential as well as essential dimensions of bildung, in other words human- as well as content-related aspects of arts are accounted for. By that, this study contributes with an understanding regarding older people and arts activities that complete what is already found in community dance and community music research (Barr, 2013; Green, 2000; Hartogh, 2016; Higgins, 2007; Lehrman, 1976).

In addition, it has become clear that conscious choices must be made in planning, conducting, and evaluating of dance activities for older people. The situation for each and every arts-based educational activity will need to be examined for what can possibly be taught and learned in relation to the participants, and for how it can be organized and offered. Bodies, stories, room, imaginations, atmosphere, forms of expression and continual dialogue must be taken into consideration. Hence, social benefits and wellbeing among older people cannot be the main aim of the activity (cf. Camic et. al., 2014; In-Sil et. al., 2015; Lee, et. al., 2010; Pearce \& Lillyman, 2015; Phinney et. al., 2014), but could come as an important bonus. All mentioned dimensions of arts knowledge must 
always be taken into account (Ferm Thosrgersen, 2013; Nielsen 1998; Varkøy, 2017). Existential, emotional, and bodily dimensions of arts education have to be balanced in relation to performative, audio-visual, and structural ones. Only then, will people have the opportunity to experience themselves as 'whos', to feel that they have equal opportunity to participate and learn, to be in the space of wonder, to become their full potential, to bodily experience who they are, and to run projects in togetherness, independent of age, or any other basis for discrimination. Söderman and Westvall's study (2017) touches upon these aspects, but the current study underscores the importance and contributes with theoretical tools through which it becomes possible to view, and perhaps develop, current and future arts educational activities for older people in the direction of achieving a transformation of self-conception. Of course, the current approach puts demands on arts teachers, but if we take aesthetic dimensions of education seriously, we must rise to that challenge. Otherwise, community activities for older people risk preserving inequalities related to age and aging.

The dance activities seem to give the older people the opportunity to remain themselves, even as they become different (cf. de Beauvoir, 1976/1992). They learn to know themselves and each other as dancing human beings, and the world as a place for being and becoming. The intertwining transformative process of becoming, independent of age, could be seen as a crosspiece or a meeting place of dancers' and a choreographer's selves with the world of different and unique life and learning experiences, and unpredictable turns, challenges, and wonders. For the choreographer, physical movement, speech, and dance-teaching activities are central. Dance knowledge seems to be embodied among the older participants, and thereby constitutes the flesh of practice and the field of becoming. In the intertwined chiasmatic interplay with each other, with life-stories, with the dance, and the music, the participants discovered who they are and who they could become as (dancing) human beings. One task for the choreographer is to orient older people to what lies beyond the immediately present, and thereby draw them into a magical but now taken-for-granted realm of meeting each other and themselves, in a world of ideas characterised by physical movements, speech, and artistic expressions. The double chiasmatic constitution of the flesh where the older dancers meet each-others and oneselves in the dance activities offers opportunities for the transformation of selfconception. In other words, artistic activities provided in the ways presented the article can be defined as life-long learning.

\section{Notes}

1 Information about the workshops was communicated through an e-mail sent out through the choreographer's own connections, as well as through organizations connected to older people in Stockholm. There are a rather large number of activities for older people available in Sweden, not least in the bigger cities, but contemporary dance, and activities focusing on artistic expression are not so common. All applicants, from various backgrounds, were accepted.

\section{References}

Alrø, S., \& Rønholt, H. (2003). Video i Paedagogisk Forskning - Krop og Udtryk i Bevagelse. Köpenhemn: Hovedland forlag.

Andersson, N., \& Ferm Almqvist, C. (2021). "'o get the chance to dance myself" - dance as democracy among people 65+. Research in Dance Education, 21(3), 262-279. 
Arendt, H. (1958). The Human Condition. Chicago: The University of Chicago Press.

Barr, S. (2013). Learning to Learn: A Hidden Dimension within Community Dance Practice. Journal of Dance Education, 13(4), 115-121.

Bengtsson, J. (1998). Fenomenologiska Utflykter. Göteborg: Daidalos.

Burman, A. (2018). Kultiverandet av det Mänskliga: Essäer omLiiberal Education, Bildning och Tänkande. Göteborg: Daidalos.

Butterwick, S., \& Roy, C. (2018). Introduction to Finding Voice and Listening: The Potential of Community and Arts-based Adult Education and Research. Canadian Journal for the

Study of Adult Education, 30(2), 1-9. Retrieved from https://cjsae.library.dal.ca/index.php/cjsae/article/view/5443

Camic, P. M., Tischler, V. \& Pearman, C. H. (2014). Viewing and Making Art Together: A Multi-Session Art-Gallery-Based Intervention for People with Dementia and their Carers. Aging \& Mental Health, 18(2), 161-168.

de Beauvoir, S. (1976/1992). The Coming of Age. New York: W. W. Norton and Company.

de Beauvoir, S. (1949/2011/2012). Det andra könet. Stockholm: Norstedt.

Ekberg, N., \& Schwieler, E. (2020). Evolving Bildung, Technology and Streaming Art. Popular Communication, 1-16. https://doi.org/10.1080/15405702.2020.1744608

Ferm Almqvist, C., \& Andersson N. (2019). To Offer Dance as Aesthetic Experience and Communication Among People 65+. International Journal of Education in the Arts. International Journal of Education and the Arts, 20(12).

Ferm Thorgersen, C. (2013). Lived music - multi-dimensional musical experience: Implications for music education. Philosophy Study, 3(12), 1124-1134.

Green, J. (2000). Power, service and reflexivity in a community dance project. Research in Dance Education, 1(1), 53-67.

Hallam, S., Creech, A., Varvarigou, M., McQueen., H. \& Gaunt, H. (2013). Different Ways of Experiencing Music-Making in Later Life: Creative Music Sessions for Older Learners in East London. Research Studies in Music Education, 35(1), 103-118.

Hallam, S., Creech, A., Varvarigou, M., McQueen, H., \& Gaunt, H. (2014). Does Active Engagement in Community Music Support the Well-being of Older people? Arts \& Health: International Journal for Research, Policy \& Practice, 6(2), 101-116.

Hallam, S., Creech, A., Varvarigou, M., McQueen, H., \& Gaunt, H. (2016), The Facilitator of Community Music-Making with Older Learners: Characteristics and Motivations. International Journal of Music Education, 34(1), 19-31.

Hartogh, T. (2016). Music Geragogy, Elemental Music Pedagogy and Community Music Didactic Approaches for Making music in Old Age. International Journal of Community Music, 9(1), 35-48. doi: 10.1386/ijcm.9.1.35_1

Higgins, L. (2007). Acts of Hospitality: The Community in Community Music. Music Education Research, 9(2), 281-292.

In-Sil, P., Ji-Young, K., Soon-Jeong, C., \& Hyun-Jung, P. (2015). The Relationship Between Wellbeing Tendency, Health Consciousness, and Life Satisfaction Among Local Community Dance Program Participants. Procedia Social and Behavioral Sciences, 205, 211-220.

Kozel, S. (2007). Closer: Performance, Technologies, Phenomenology. Cambridge, MA: MIT Press.

Laes, T. (2015). Empowering Later Adulthood Music Education: A Case Study of a Rock Band for ThirdAge Learners. International Journal of Music Education, 33(1), 51-65.

Lee Y. Y., Chan M. F., \& Mok E. (2010). Effectiveness of Music Intervention on the Quality of Life of Older People. Journal of Advanced Nursing, 66(12), 2677-2687.

Lerman, L. (1976). Teaching Dance to Senior Adults. Springfield, Illinois: Charles C. Thomas Publisher.

Merleau-Ponty, M. (1962). Phenomenology of Perception. London: Routledge.

Merleau-Ponty, M. (1964). The Primacy of Perception: And Other Essays on Phenomenological Psychology. Evanston: Northwestern University Press.

Merleau-Ponty, M. (1968). The Visible and the Invisible: Followed by Working Notes. Evanston: Northwestern University Press.

Nielsen, F.V. (1998). Almen musikdidaktik. $2^{\text {nd }}$ revised edition. København: Akademisk forlag.

Pearce, R., \& Lillyman, S. (2015). Reducing Social Isolation in a Rural Community Through Participation in Creative Arts Projects. Nursing Older People, 27(10), 33-38.

Phinney, A., Moody, E. M., \& Small, J. A. (2014). The Effect of a Community-Engaged Arts Program on Older Adults' Well-Being. Canadian Journal on Aging, 33(3), 336-345. 
[16] Ferm Almqvist

Söderman, J., \& Westvall, M. (2017). Community Music as Folkbildning: A study of a Finnish Cultural Association in Sweden. International Journal of Community Music, 10(1), 45-58.

The Swedish Arts Council. (2019). Cultural Policy Objectives. http://www.kulturradet.se/en/In-English/Cultural--policy--objectives

The Swedish Parliament. (2015). The Basic Law on Freedom of Expression. (https://www.riksdagen.se/globalassets/07.-dokument--lagar/the-fundamental-law-on-freedom-ofexpression-2015.pdf) (20210315)

UNESCO. (2019). Unesco and the Universal Declarations of Human rights. https://en.unesco.org/udhr\%20

van Manen, M. (1990). Researching Lived Experience: Human Science for an Action Sensitive Pedagogy. State University of New York Press, Albany.

Varkøy, Ø. (2017). Musikk - dannelse og eksistens. Oslo: Cappelen Damm Akademisk.

Wildemeersch, D. (2019). Editorial: Adult Education and the Aesthetic Experience. European Journal for Research on the Education and Learning of Adults, 10(2), 117-121. 